\title{
The Discovery and Characterization of a Proton-Gated Sodium Current in Rat Retinal Ganglion Cells
}

\author{
Sarah Lilley, ${ }^{1}$ Paul LeTissier, ${ }^{2}$ and Jon Robbins ${ }^{3}$ \\ 1,3Neural Injury and Repair Group, Centre for Neuroscience Research, King's College London, Guy's Campus, London, SE1 1UL, United Kingdom, and \\ ${ }^{2}$ Division of Neuroendocrinology, National Institute for Medical Research, The Ridgeway, Mill Hill, London, NW7 1AA, United Kingdom
}

The conduction of acid-evoked currents in central and sensory neurons is now primarily attributed to a family of proteins called acid-sensing ion channels (ASICs). In peripheral neurons, their physiological function has been linked to nociception, mechanoreception, and taste transduction; however, their role in the CNS remains unclear. This study describes the discovery of a proton-gated current in rat retinal ganglion cells termed $\mathrm{I}_{\mathrm{Na}(\mathrm{H}+)}$, which also appears to be mediated by ASICs. RT-PCR confirmed the presence of ASIC mRNA (subunits la, 2a, 2b, 3, and 4) in the rat retina. Electrophysiological investigation showed that all retinal ganglion cells respond to rapid extracellular acidification with the activation of a transient $\mathrm{Na}^{+}$current, the size of which increases with increasing acidification between pH 6.5 and pH 3.0. $\mathrm{I}_{\mathrm{Na}(\mathrm{H}+)}$ desensitizes completely in the continued presence of acid, its current-voltage relationship is linear and its reversal potential shifts with $\mathrm{E}_{\mathrm{Na}} \cdot \mathrm{I}_{\mathrm{Na}(\mathrm{H}+)}$ is reversibly inhibited by amiloride $\left(\mathrm{IC}_{50}, 188 \mu \mathrm{M}\right)$ but is resistant to block by TTX $(0.5 \mu \mathrm{M})$, $\mathrm{Cd}^{2+}(100 \mu \mathrm{M})$, procaine $(10 \mathrm{mM})$, and is not activated by capsaicin $(0.5 \mu \mathrm{M}) . \mathrm{I}_{\mathrm{Na}(\mathrm{H}+)}$ is not potentiated by $\mathrm{Zn}^{2+}(300 \mu \mathrm{M})$ or Phe-MetArg-Phe-amide $(50 \mu \mathrm{M})$ but is inhibited by neuropeptide-FF $(50 \mu \mathrm{M})$. Acute application of $\mathrm{pH} 6.5$ to retinal ganglion cells causes sustained depolarization and repetitive firing similar to the trains of action potentials normally associated with current injection into these cells. The presence of a proton-gated current in the neural retina suggests that ASICs may have a more diverse role in the CNS.

Key words: acid-sensing ion channel; retinal ganglion cell; sodium channel; proton-gated current; retina; $\mathrm{pH}$

\section{Introduction}

Proton-gated currents are emerging as a common feature of mammalian central and sensory neurons. In peripheral tissues, where ischemia-induced acidosis can measure several $\mathrm{pH}$ units, these currents have been implicated in nociception (Reeh and Steen, 1996; Benson and Sutherland, 2001), in addition to the physiological processes of mechanoreception (Price et al., 2000) and taste transduction (Gilbertson et al., 1993). The functional significance of currents gated by protons in the brain is less obvious, because the brain is well protected from such large $\mathrm{pH}$ fluxes by the carbonic anhydrase-catalyzed $\mathrm{CO}_{2} / \mathrm{HCO}_{3}$ buffering system (Chesler, 1990). Nevertheless, neurons from various regions of the brain and spinal cord respond to rapid extracellular acidification by conducting non-voltage-dependent cation currents carried predominantly, if not exclusively, by $\mathrm{Na}^{+}$. These currents are inhibited by the diuretic amiloride but are insensitive to TTX (Ueno et al., 1992; Baumann et al., 1996; Li et al., 1997; Varming, 1999).

In the CNS, there is strong evidence linking these protongated currents to a subgroup of the degenerin (DEG)-epithelial

Received July 4, 2003; revised Oct. 28, 2003; accepted Nov. 12, 2003.

This work was funded by the Wellcome Trust and University of London Central Fund. We gratefully acknowledge Drs. Melanie Clements and Pam Houston for their technical assistance.

Correspondence should be addressed to Dr. Jon Robbins, Neural Injury and Repair Group, Centre for Neuroscience Research, King's College London, Guy's Campus, London, SE1 1UL, UK. E-mail: jon.robbins@kcl.ac.uk.

S. Lilley's present address: Division of Neurophysiology, National Institute for Medical Research, The Ridgeway, Mill Hill, London, NW7 1AA, UK.

D0I:10.1523/JNEUROSCI.3191-03.2004

Copyright $\odot 2004$ Society for Neuroscience $\quad$ 0270-6474/04/241013-10\$15.00/0
$\mathrm{Na}^{+}$channel (ENaC) superfamily known as acid-sensing ion channels (ASICs). This evidence includes the absence of protongated currents in the hippocampal neurons of ASIC 1a knock-out mice (Wemmie et al., 2002), the distribution of ASIC-encoding mRNA throughout the CNS, and extensively studied parallels between neuronal proton-gated currents and those recorded from transfected cells expressing ASIC channel protein (Lingueglia et al., 1997; Waldmann et al., 1997; de Weille et al., 1998; Bassler et al., 2001). ASICs share their protein structure, amiloride sensitivity, and conduction of $\mathrm{Na}^{+}$-selective currents with the rest of the ENaC superfamily (de la Rosa et al., 2000) but are the only family members to be activated by protons. From ASIC genes cloned to date, seven subunit products (including splice variants) have been identified: ASIC1a, 1b, 1b2, 2a, 2b, 3, and 4; all but ASIC1b and $1 \mathrm{~b} 2$ have been found in central neurons. By homomultimeric or heteromultimeric association of their subunits, ASICs conduct currents with a range of subtle variations in current characteristics. These reflect regional variations seen in "native" proton-gated currents recorded from both central and peripheral nervous tissue. With the recent synaptic localization of some ASICs (Wemmie et al., 2002), highly localized pH changes accompanying neurotransmitter release from vesicles may be large enough to briefly overcome interstitial buffering and activate these channels, perhaps giving ASICs a role in normal neurotransmission.

The retina is a functionally distinct region of central neurons known to contain ENaCs (Matsuo, 1998; Golestaneh et al., 2000) but has been demonstrated only recently to contain ASICs 
Table 1. Nomenclature, cloning, and RT-PCR primer sequence details of the six rat ASIC subunits examined for their presence in the retina

\begin{tabular}{|c|c|c|c|c|c|}
\hline Subunit & Accession number & Alternative published names & $\begin{array}{l}\text { Forward }(f) \text { and reverse }(r) \text { primer } \\
\left.\text { sequences (listed } 3^{\prime} \text { to } 5^{\prime}\right)\end{array}$ & $\begin{array}{l}\text { Annealing temperature } \\
\left({ }^{\circ} \mathrm{C}\right)\end{array}$ & $\begin{array}{l}\text { Product size } \\
\text { (nucleotides) }\end{array}$ \\
\hline ASIC1a & U94403 (rat) & $\mathrm{BNaC2}, \mathrm{ASIC}$ & $\begin{array}{l}\text { f: GCTTTAGCCAAGTCTCCAAG } \\
\text { r:AGTCAAAGAGTTCCAGCACG }\end{array}$ & 58.0 & 1064 \\
\hline ASIC1b & AJ006519 (rat) & ASIC $-\beta$ & $\begin{array}{l}\text { f: } \quad \text { CTCTATTGTTCCTACTGTGG } \\
\text { r: } \text { CTTCTGGCACTTTCCACGTC }\end{array}$ & 50.5 & 905 \\
\hline $\mathrm{ASIC} 2 \mathrm{a}$ & NM_012892 (rat) & $\mathrm{BNaC1}, \mathrm{MDEG}, \mathrm{MDEG} 1$ & $\begin{array}{l}\text { f: GCTCTACTGCAAGTTCAAGG } \\
\text { r: ACACTCCTTGTGCTGCTCAG }\end{array}$ & 58.0 & 522 \\
\hline$A S I C 2 b$ & Y14635 (rat) & MDEG2 & $\begin{array}{l}\text { f: ATATGCTGCTCTCCTGCAAG } \\
\text { r: ACACTCCTTGTGCTGCTCAG }\end{array}$ & 58.0 & 529 \\
\hline ASIC3 & AF013598 (rat) & DRASIC & $\begin{array}{l}\text { f: TGACATGGCACAACTCTACG } \\
\text { r: TCATTCGACAGCCACACTTC }\end{array}$ & 61.0 & 568 \\
\hline ASIC4 & $\begin{array}{l}\text { AJ242554 (rat) } \\
\text { (truncated protein in pituitary: AJ271642) }\end{array}$ & SPASIC & $\begin{array}{l}\text { f: TATAGTGTGTCTGCCTGCCG } \\
\text { r: TGTAGGTCTCATTGCGGTTG }\end{array}$ & 58.0 & 288 \\
\hline
\end{tabular}

(Brockway et al., 2002; Maubaret et al., 2002). Retinal ganglion cells (RGCs) are an interesting potential location of these channels as they undergo constant, rapid stimulation in both light and darkness while collating all visual input from the retina. They exhibit a high level of metabolic activity, which has been shown to cause transient interstitial acidification around the optic nerve during normal neurotransmission (Davis et al., 1987). The present study examines the rat retina for evidence of ASIC channels and characterizes the response of RGCs to extracellular acidification. A brief report of some of this data has been published (Lilley and Robbins, 2001).

\section{Materials and Methods}

All animal procedures were approved by the university ethics committee and adhere to United Kingdom Home Office regulations.

Reverse transcriptase-PCR. Hooded Lister rats [postnatal d (P) 18; either gender)] were killed by decapitation. The eyes were removed, and the retina was extracted. From the same animals, brain tissue (divided in a nonregion-specific manner) and the dorsal root ganglia (DRGs) were used to provide positive PCR controls. RNA was extracted using a modified version of the method described by Chomczynski and Sacchi (1987) involving the use of Trizol ( $1 \mathrm{ml}$ per $100 \mathrm{mg}$ of tissue; Invitrogen, Paisley, UK). After extraction, the RNA was resuspended in RNase-free water (Sigma, Poole, UK), and sample content-purity was assessed by spectrophotometry. All reagents for cDNA generation were supplied by Promega (Hawthorne, Australia). Samples of nucleotide solution $(20 \mu \mathrm{l})$ containing $5 \mu \mathrm{g}$ of extracted RNA, 1 pmol oligo-dT primers, and RNasefree water were denatured at $70^{\circ} \mathrm{C}$ for $5 \mathrm{~min}$. These were immediately cooled on ice before the addition of $10 \mathrm{nmol}$ of deoxy-NTP (dNTP) substrate [equimolar dATP, dGTP, dCTP, and deoxythymidine triphosphate $(\mathrm{dTTP})], 5 \times$ Moloney murine leukemia virus $(\mathrm{M}-\mathrm{MLV})$ reverse transcriptase (RT) reaction buffer, and $0.5 \mu \mathrm{l}$ of RNAsin. After $5 \mathrm{~min}$ at room temperature, $1 \mu \mathrm{l}$ of M-MLV RT (200 U/ $\mu \mathrm{l})$ was added, and the sample was incubated at $42^{\circ} \mathrm{C}$ for $1 \mathrm{hr}$. Repeating the above process with the omission of the reverse transcriptase produced negative control samples for subsequent PCR reactions. PCR reactions were performed in volumes of $50 \mu \mathrm{l}$ containing PCR buffer, including $15 \mathrm{mM} \mathrm{MgCl}_{2}$ (Roche Products, Hertforshire, UK), $10 \mathrm{nmol}$ of dNTP substrate (comprising equimolar dATP, dGTP, dCTP, and dTTP), $10 \mathrm{nmol}$ each of forward and reverse primers (Sigma; Genosys, The Woodlands, TX) (see Table 1 for details), $0.5 \mu \mathrm{l}$ of a 16:1 (unit:unit) mix of Taq polymerase and Pfu (Roche Products), DNase- and RNase-free water (Sigma), and $1 \mu \mathrm{l}$ of either cDNA (RT + reaction) or negative control $(\mathrm{RT}-$ ) generated in the previous step. PCR was performed in 34 cycles of denaturation $\left(94^{\circ} \mathrm{C}\right.$ for $30 \mathrm{sec}$ ), annealing (see Table 1 for subunit-specific temperatures), and extension $\left(72^{\circ} \mathrm{C}\right.$ for $\left.2 \mathrm{~min}\right)$. Products were viewed by $1.2 \%$ agarose gel electrophoresis.

Cell culture and RGC identification. RGCs were cultured as described by Robbins et al. (2003). Retinas from P2-P20 Hooded Lister rats were subjected to digestion by papain and gentle trituration, and the cell sus- pension was centrifuged through a gradient mixture. Cells were resuspended by additional trituration to ensure good separation of the cells in culture. Mixed retinal cultures were plated onto poly-L-lysine-coated glass coverslips and maintained in modified DMEM-HBSS (Invitrogen) at $37^{\circ} \mathrm{C}$ and $5 \% \mathrm{CO}_{2}$ for $1-10 \mathrm{~d}$ before experimentation. RGCs were identified routinely from other cell types on the basis of soma diameter $(>12 \mu \mathrm{m})$, which was based on correlation with immunocytochemical staining (Thy1.1; Chemicon, Temecula, CA; FITC-IgC; Boehringer Mannheim, Mannheim, Germany) and patterns of electrical activity recorded using whole-cell current clamp (Lilley, 2001; Robbins et al., 2003).

Electrophysiology. Whole-cell membrane currents were recorded via a single electrode using the patch-clamp technique. All voltage-clamp recordings were taken from cells cultured for 1-2 d only to limit axonal development and thereby minimize space-clamp errors. Cells were bathed in solution containing (in $\mathrm{mm}$ ): $140 \mathrm{NaCl}, 5 \mathrm{KCl}, 2.5 \mathrm{CaCl}_{2}, 1$ $\mathrm{MgCl}_{2}, 10$ glucose, and 10 HEPES, pH adjusted to 7.33 using $\mathrm{NaOH}$. In ion substitution experiments, $\mathrm{NaCl}$ was sequentially reduced from 140 to 45 to $14 \mathrm{~mm}$ and replaced with equimolar TEA-Cl, and the $\mathrm{pH}$ was adjusted using $\mathrm{KOH}$. For $\mathrm{Ca}^{2+}$-free recordings, $\mathrm{CaCl}_{2}$ was omitted, 1 mM EGTA was added, and $\mathrm{MgCl}_{2}$ increased to $5 \mathrm{~mm}$. Extracellular solution for all voltage-clamp recordings contained $0.5 \mu \mathrm{M}$ TTX (Tocris Cookson, Bristol, UK). Polished borosilicate glass pipettes (6-12 M $\Omega$ ) were filled with the following (in mM): $110 \mathrm{Cs}^{+}$acetate, $20 \mathrm{CsCl}, 20 \mathrm{NaCl}$, 10 HEPES, 3 EGTA, $3 \mathrm{MgCl}_{2}$, and $1 \mathrm{CaCl}_{2}$, pH adjusted to 7.33 with $\mathrm{CsOH}$. For acute application of acid or other ligands to an individual cell, membrane voltage of the target cell was maintained at $-80 \mathrm{mV}$. Rapid application was achieved using either single- or triple-barreled pipettes connected to a NeuroPhore BH-2 pressure ejection system (Digitimer, Hertfordshire, UK) or by U-tube perfusion as stated in Results. Where current-voltage relationships have been measured, pressure-pulse applications were combined with $15 \mathrm{mV}$ depolarizations in cell-holding voltage over the range of -80 to $55 \mathrm{mV}$ (each voltage being held for $40 \mathrm{sec}$ before pressure pulses were applied to inactivate transient $\mathrm{Ca}^{2+}$ currents). Pressure-pulse triggering, voltage protocol application, and all data acquisition (sampled at $2 \mathrm{kHz}$ ) were achieved using pClamp6 via a Digidata 1200 interface (Axon Instruments, Foster City, CA). Cell responses were amplified using an Axopatch 1C and CyberAmp (Axon Instruments) with low-pass filtering at $600 \mathrm{~Hz}$.

Figures comprising voltage-clamp data from multiple cells are plotted in terms of current density $(\mathrm{pA} / \mathrm{pF})$ : a measure of current per unit area of cell membrane in which area is directly proportional to capacitance. Capacitance measurements for each cell were derived by recording uncompensated capacitance artifacts evoked by a short $20 \mathrm{mV}$ hyperpolarizing step from which only the "fast pipette" component had been removed by compensation. The decay phase of these artifacts was fitted with an exponential curve, the time constant from which was divided by the series resistance measured for the cell to give an approximation of cell capacitance. All voltage-clamp recordings were then made with $80 \%$ series resistance compensation added via the amplifier, unless otherwise stated. Adjustment of reversal potentials to allow for ionic activity was 
done with appropriate ion activity coefficients as listed by Robinson and Stokes (1959). For example, $140 \mathrm{~mm} \mathrm{NaCl} \times 0.778=108.9 \mathrm{~mm}$ free $\mathrm{Na}^{+}$ ions at $25^{\circ} \mathrm{C}$.

Current-clamp recordings were made from cells grown in culture from 3-10 d, which had begun to develop axonal processes. Standard extracellular solution was used with the omission of TTX. Intracellular solution comprised the following (in $\mathrm{mm}$ ): $120 \mathrm{~K}^{+}$acetate, $20 \mathrm{KCl}, 10$ HEPES, 3 EGTA, $3 \mathrm{MgCl}_{2}$, and $1 \mathrm{CaCl}_{2}$, adjusted to $\mathrm{pH} 7.33$ with $\mathrm{KOH}$.

Test $\mathrm{pH}$ solution consisted of extracellular solution that was appropriate to the experiment acidified to the required $\mathrm{pH}$ using $\mathrm{HCl}$. The $\mathrm{pH}$ of these acidified solutions was checked both before and after all experiments, because some acidity levels were beyond the normal range of the buffer (HEPES). However, $\mathrm{pH}$ was found to be stable throughout, so no buffering modifications were made. We were unable to use acid solutions stronger than $\mathrm{pH} 3.0$, because this disrupted the seal between recording pipette and the cell membrane, hence the $\mathrm{pH}$ activation curve has not been "normalized" to a maximum value. Neuropeptide-FF (N-FF) and Phe-Met-Arg-Phe-amide (FMRFamide) were supplied by Peninsular (St. Helen's, UK). Amiloride, capsaicin, and all other reagents were from Sigma.

Intracellular $\mathrm{Ca}^{2+}$ measurement. Procedures were similar to that described by Hayat et al. (2003). Briefly, mixed retinal cells cultured for 2-5 d were loaded with $5 \mu \mathrm{M}$ 1-[2-amino-5-(6-carboxyindol-2-yl)phenoxy]2-(2'-amino- $5^{\prime}$-methylphenoxy)ethane- $\mathrm{N}, \mathrm{N}, \mathrm{N}^{\prime} \mathrm{N}^{\prime}$-tetraacetic acid pentaacetoxymethyl ester (INDO-1/AM; Calbiochem, Nottingham, UK) in dimethyl sulfoxide (DMSO; Sigma) for $1 \mathrm{hr}$ at $37^{\circ} \mathrm{C}$ in the dark. The cultures were viewed using a Nikon Diaphot microscope and 330-380 $\mathrm{nm}$ excitation from a xenon light source. Fluorescent emission from the cells was measured via photomultiplier tubes at both 405 and $488 \mathrm{~nm}$, amplified using a purpose-built ratio amplifier (T. Dyett, University College London, London, UK) and data acquired on a personal computer running pClamp6 software (Axon Instruments). Calcium calibration was performed as described by Hayat et al. (2003), in which $\left[\mathrm{Ca}^{2+}\right]_{\mathrm{i}}$ (in $\mathrm{nM})=722(R-0.28 / 3.94-R)$, where $R$ is emission ratio.

All results are given as mean \pm SEM. Curve fitting was performed using the equation $y=\left[A_{1}-A_{2} / 1+\left(x / x_{\mathrm{o}}\right)^{p}\right]+A_{2}$, where $A_{1}$ is minimum, $A_{2}$ is maximum, $p$ is slope, and $x_{\mathrm{o}}$ is midpoint location.

\section{Results}

Presence of ASIC-encoding mRNA in the retina

The presence of ASIC-encoding mRNA in the rat retina was confirmed using RT-PCR (Fig. 1). Positive control reactions were performed using cDNA generated from rat brain (ASIC subunits 1a, 2a, 2b, 4) and DRGs (ASIC $1 \mathrm{~b}$ and 3) from which primerannealing temperatures were deduced. When these experiments were repeated alongside rat retinal cDNA, the primers for subunits $1 \mathrm{a}, 2 \mathrm{a}, 2 \mathrm{~b}$, and 4 produced clear positive results, and a faint positive result was seen with the primers for ASIC 3. Consistent with data from other CNS regions, no evidence of the ASIC 1b subunit was found in the retina using this method.

Relationship between extracellular $\mathrm{pH}$ and $\mathrm{I}_{\mathrm{Na}(\mathrm{H}+)}$ activation Initial observations of the RGC proton-gated current $\left(\mathrm{I}_{\mathrm{Na}(\mathrm{H}+)}\right)$ were made by the pressure ejection of acidified extracellular solution, $\mathrm{pH} 4.5$, directly onto individual cells. In every cell tested $(n=79)$, this evoked a rapid inward current. In 30 of these cells held at $-80 \mathrm{mV}$, the peak inward current was $1056 \pm 72 \mathrm{pA}$. These currents peaked within $200-450 \mathrm{msec}$ of the start of the pressure pulse. Despite desensitizing fully in the continued presence of the acid, currents could be re-evoked, with no reduction in current amplitude, after $40 \mathrm{sec}$ perfusion with control, $\mathrm{pH}$ 7.33, extracellular solution. Examples of $\mathrm{I}_{\mathrm{Na}(\mathrm{H}+)}$ evoked over a range of membrane potentials from -80 to $+40 \mathrm{mV}$ are shown in Figure $2 A$.

$\mathrm{I}_{\mathrm{Na}(\mathrm{H}+)}$ in rat RGCs was evoked by rapid (msec) acidification only. Decreasing extracellular $\mathrm{pH}$ via the chamber perfusion sys-


Figure 1. Evidence for the presence of ASIC-encoding mRNA in the rat retina. Whole retinal RNA was subject to RT-PCR using primers designed to detect the first six ASIC subunits cloned to date. Positive controls were performed using rat brain or DRG CDNA as appropriate. All RT-PCR experiments were repeated with the omission of reverse transcriptase to provide negative controls containing only genomic DNA rather than CDNA. Arrows indicate size of bands expected in RT+ samples.

tem over several seconds did not appear to evoke a depolarizing current, and there was no apparent overall change in membrane resistance with slow acidification.

The relationship between extracellular $\mathrm{pH}$ and $\mathrm{RGC}$ response 
A. $\mathrm{pH} 7.3$
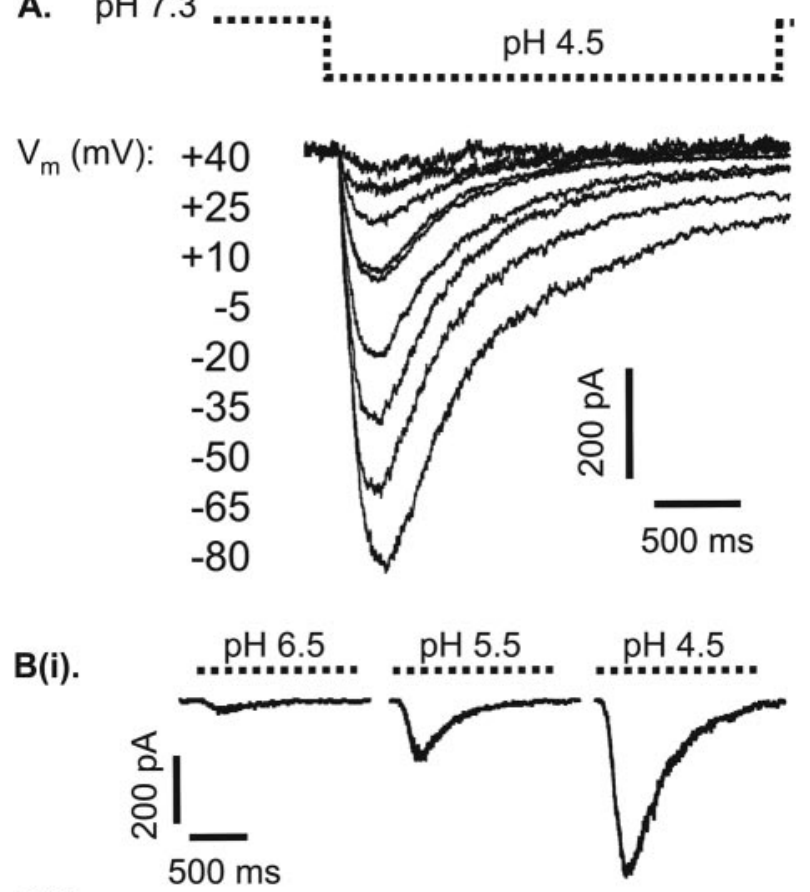

B(ii).

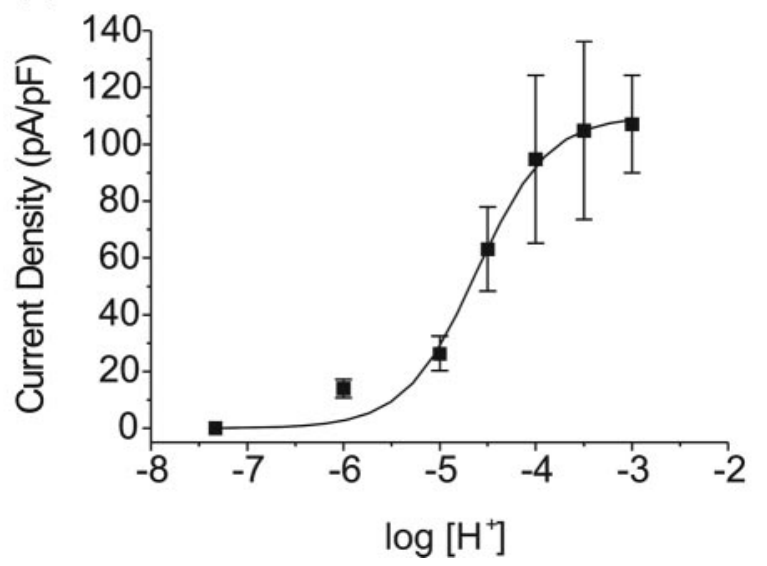

Figure 2. A, Example of $\mathrm{pH}$ 4.5-evoked currents in a single rat retinal ganglion cell at different membrane potentials. Cells were voltage clamped at the membrane potentials indicated in the figure. These membrane voltages were held for $40 \mathrm{sec}$ before a $2 \mathrm{sec}$ pressure pulse of acidified extracellular solution (pH 4.5) was applied to ensure any voltage-gated conductances were inactivated (dashed line indicates acid application). Bi, Currents evoked by different levels of extracellular acidification while cells were voltage-clamped at $-80 \mathrm{mV}$ (application by U-tube). Bii, Relationship between level of extracellular acidification and current activation in retinal ganglion cells. The $\mathrm{pH}$-response graph, expressed in terms of current density, shows mean $( \pm$ SEM) results for nonconsecutively administered $\mathrm{pH}$ test pulses recorded as in Bi. Each data point represents the mean current- density value for $7-13$ cells at the given $\mathrm{pH}$ level. Test pulses of acid were administered in a randomized block design. Logistic fit: slope, 1.38; $\mathrm{EC}_{50}, \mathrm{pH}$ 4.52 .

was quantified using the U-tube system to attain an absolute, rather than relative, $\mathrm{pH}$ change across the surface of the target cell. Test solutions of $\mathrm{pH} 6.0,5.0,4.5,4.0,3.5$, or 3.0 were applied in $3 \mathrm{sec}$ pulses to each cell and repeated at $1 \mathrm{~min}$ intervals between which the cell was perfused with $\mathrm{pH} 7.33$ solution. The mean current density for 7-13 cells at each given $\mathrm{pH}$ level is shown in Figure 2 Bii with individual examples in Figure 2Bi. Peak inward current clearly increases with increasing acidity. The threshold for activation is $\mathrm{pH} 6.5$, and current density approaches a maximum at $\mathrm{pH}$ 3.0. Half-maximal activation occurs at $\mathrm{pH} 4.5$, which
A. $\mathrm{pH}$ stimulus

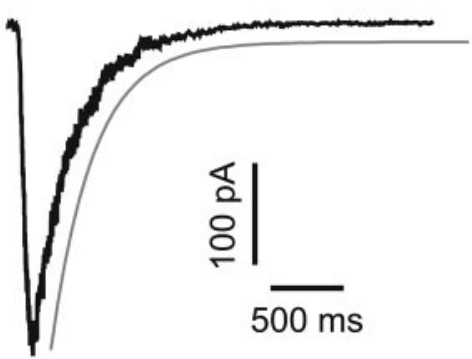

B.

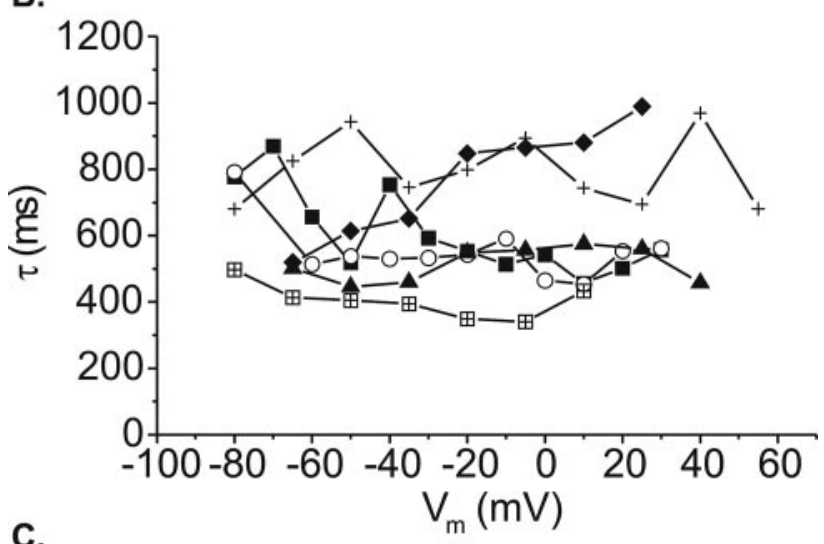

C.

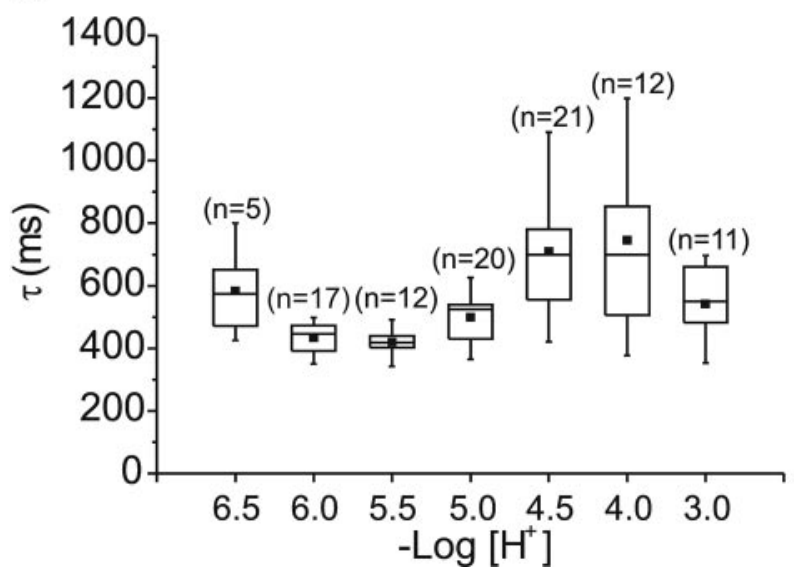

Figure 3. Current desensitization in the continued presence of acid. A, All time constants were derived from single exponential decay curves fitted as shown by the gray line. Dashed line represents 2.25 sec acidification by pressure pulse or 3 sec acidification by U-tube. $B$, Variation in the time constant of pH 4.5-evoked currents recorded from six rat retinal ganglion cells (linked symbols represent individual cells) while the cells were voltage clamped over a range of membrane potentials. Acid was applied by pressure-pulse ejection. C, Variation in the time constant of currents evoked by different strengths of acid recorded while cells were voltage clamped at a constant $-80 \mathrm{mV}$ (acid was applied by U-tube).

is used at the test $\mathrm{pH}$ for the majority of the following experiments.

\section{Relationship between current desensitization, membrane} voltage, and extracellular $\mathrm{pH}$

Figure 3 shows the relationship between the time course of current desensitization in the continued presence of acid. The rate of desensitization and membrane voltage was examined using pressure pulses of $\mathrm{pH} 4.5$ solution over a range of membrane voltages. An exponential curve was fitted to the decay phase of each evoked current from just after the current peak to the point corresponding to the end of the acid test pulse, as shown in Figure $3 A$. The 
time constants $(\tau)$ of the exponential fits for six cells are plotted against membrane holding voltage in Figure $3 B$. All time constants were found to lie within the range of $300-1000 \mathrm{msec}$. For each cell, fluctuations can be seen across the potential range, but there is no obvious trend in the relationship between $\tau$ and membrane voltage. There was no evidence of a sustained component within the whole-cell current. All currents desensitized fully, although occasionally larger currents recorded at the more negative membrane potentials required longer than $2.25 \mathrm{sec}$ to return to baseline.

To examine the relationship between rate of current desensitization and the strength of acid applied, test pulses of acid were applied by U-tube at a membrane holding voltage of $-80 \mathrm{mV}$. Test solutions were administered in random order at $1 \mathrm{~min}$ intervals from a control $\mathrm{pH}$ of 7.33. In Figure $3 C$, the resultant time constants were pooled and plotted against $-\log \left[\mathrm{H}^{+}\right]$. Again, there is variation across the $\mathrm{pH}$ range, but all mean values lie in the $400-700 \mathrm{msec}$ range, and there is no obvious trend in the relationship between $\mathrm{pH}$ level and time course of current desensitization.

\section{Sodium is the charge-carrying ion of $\mathrm{I}_{\mathrm{Na}(\mathrm{H}+)}$}

The current-voltage relationship of the $\mathrm{pH} 4.5$-evoked current in retinal ganglion cells is shown in Figure $4 A$. Because of its very positive reversal potential $(65.1 \pm 16.9 \mathrm{mV} ; n=9)$ and in anticipation of the similarity between this and other transient neuronal proton-gated currents, $\mathrm{Na}^{+}$was investigated as a possible charge-carrying ion by measuring current-voltage relationships in different concentrations of extracellular $\mathrm{Na}^{+}$. Control $I-V$ relationships were recorded in $140 \mathrm{~mm}\left[\mathrm{Na}^{+}\right]_{\mathrm{o}}$ (Fig. 4Ai); extracellular $\mathrm{Na}^{+}$concentration was then reduced to $45 \mathrm{~mm}$ (Fig. 4Aii) or $14 \mathrm{~mm}$ (Fig. 4 Aiii) by substitution of $\left[\mathrm{Na}^{+}\right]_{\mathrm{o}}$ with equimolar TEA-Cl. Accordingly, pH 4.5 test solutions were based on the corresponding extracellular solution. Although the larger nonpermeant $\mathrm{TEA}^{+}$ions introduced a degree of outward rectification, outward currents were recorded at membrane potentials positive to $34.7 \pm 3.9 \mathrm{mV}$ in $45 \mathrm{~mm}\left[\mathrm{Na}^{+}\right]_{\mathrm{o}}$ and $6.9 \pm 0.7 \mathrm{mV}$ in $14 \mathrm{~mm}\left[\mathrm{Na}^{+}\right]_{\mathrm{o}}(n=5$ in both cases). These reversal potentials have been adjusted for ionic activity and plotted along with a slope representing the theoretical relationship between $\left[\mathrm{Na}^{+}\right]_{\mathrm{o}}$ and $\mathrm{E}_{\mathrm{Na}}$ for a pure $\mathrm{Na}^{+}$current derived using the Nernst equation in Figure $4 B$. The slope $\left(58 \mathrm{mV} / \log\right.$ fold $\left.\Delta[\mathrm{Na}]_{\mathrm{o}}\right)$ and the experimental data coincide completely, indicating that the RGC proton-gated current is carried by $\mathrm{Na}^{+}$.

$\mathrm{Ca}^{2+}$ microfluorimetry was used to confirm that no $\mathrm{Ca}^{2+}$ entered the cell through active proton-gated ion channels. Other research groups have previously noted that although the transient element of most neuronal responses to rapid extracellular acidification is conducted via $\mathrm{Na}^{+}$ions, a degree of $\mathrm{Ca}^{2+}$ conduction may be sustained by these channels (Kovalchuk et al., $1990)$. Figure $5, A$ and $B$, shows the $[\mathrm{Ca}]_{\mathrm{i}}$ measurements from a single retinal ganglion cell that has been loaded with the calcium fluorophore INDO-1/AM. Figure $5 A$ shows a comparison of $\mathrm{Ca}^{2+}$ rises evoked in response to $10 \mathrm{sec}$ pulses of either $100 \mu \mathrm{M}$ nicotine or $\mathrm{pH} 4.5$ extracellular solution in the presence and absence of the voltage-gated $\mathrm{Ca}^{2+}$ channel blocker $\mathrm{Cd}^{2+}$. This cell, like 23 of 43 others observed, showed an increase in intracellular $\mathrm{Ca}^{2+}$ in response to protons $(49.8 \pm 6.7 \mathrm{nM})$, which was blocked in the presence of $\mathrm{Cd}^{2+}$. In contrast, responses to nicotine, which admits $\mathrm{Ca}^{2+}$ ions directly through nACh receptor-linked channels, remained unaffected in the same cells. This suggests that any $\left[\mathrm{Ca}^{2+}\right]_{\mathrm{i}}$ rise seen in RGCs in response to extracellular acidification is attributable to the secondary activation of voltage-gated
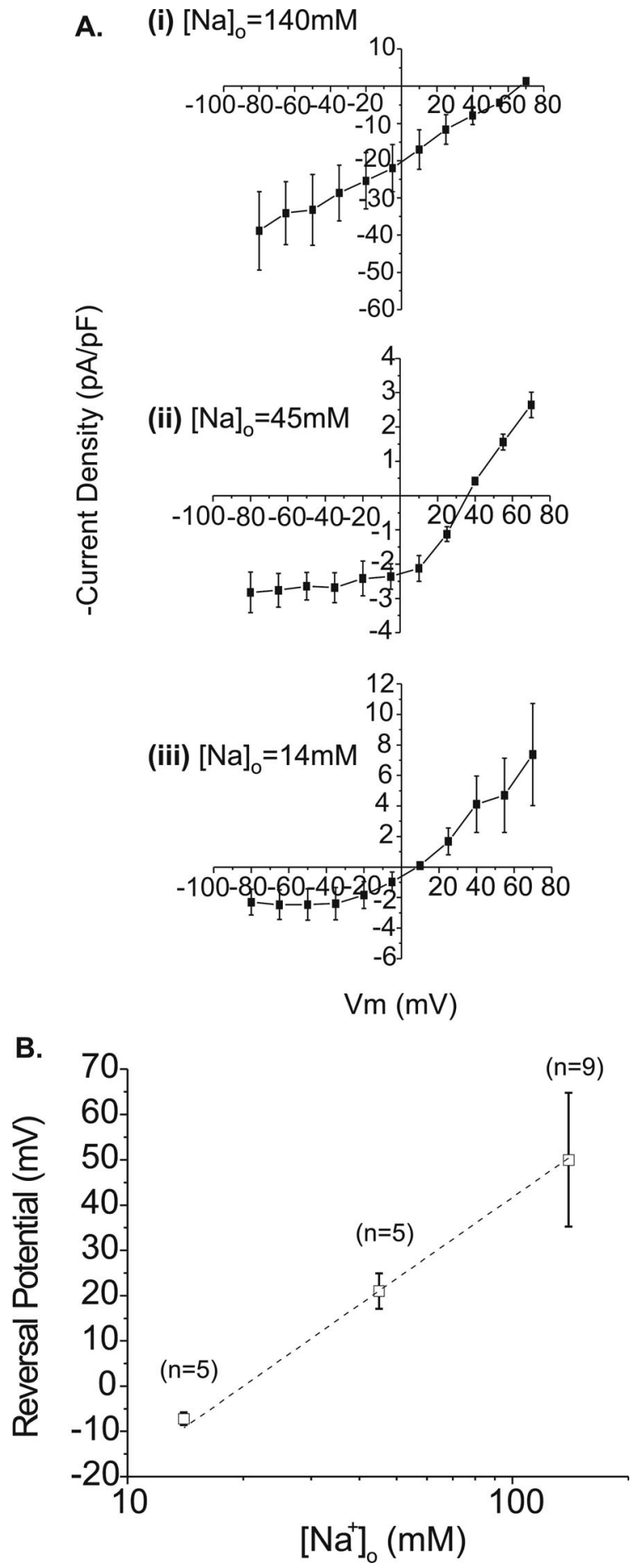

Figure 4. Varying extracellular $\mathrm{Na}^{+}$concentration causes a Nernstian shift in the reversal potential of the peak acid-evoked current in rat retinal ganglion cells. Ai-Aiii, Current-voltage relationships (normalized in terms of current density) measured in three different concentrations of extracellular $\mathrm{Na}^{+}$as indicated in the figure $\left(n=9,5\right.$, and 5 for decreasing $\left.\left[\mathrm{Na}{ }^{+}\right]_{0}\right) \cdot B$, Comparison of mean-measured reversal potentials adjusted for ionic activity (squares; \pm SEM) and theoretical reversal potentials for channels conducting $\mathrm{Na}^{+}$alone derived using the Nernst equation (dashed line).

$\mathrm{Ca}^{2+}$ channels after cell depolarization. $\mathrm{Cd}^{2+}$ does not inhibit the proton-gated current directly. Figure $5 C$ shows voltageclamp measurements of $\mathrm{pH} 4.5$-evoked currents to be identical in the presence and absence of $100 \mu \mathrm{M} \mathrm{Cd}^{2+}$. Of the other 20 cells tested, 15 showed no response to acidification, but 5 showed a 

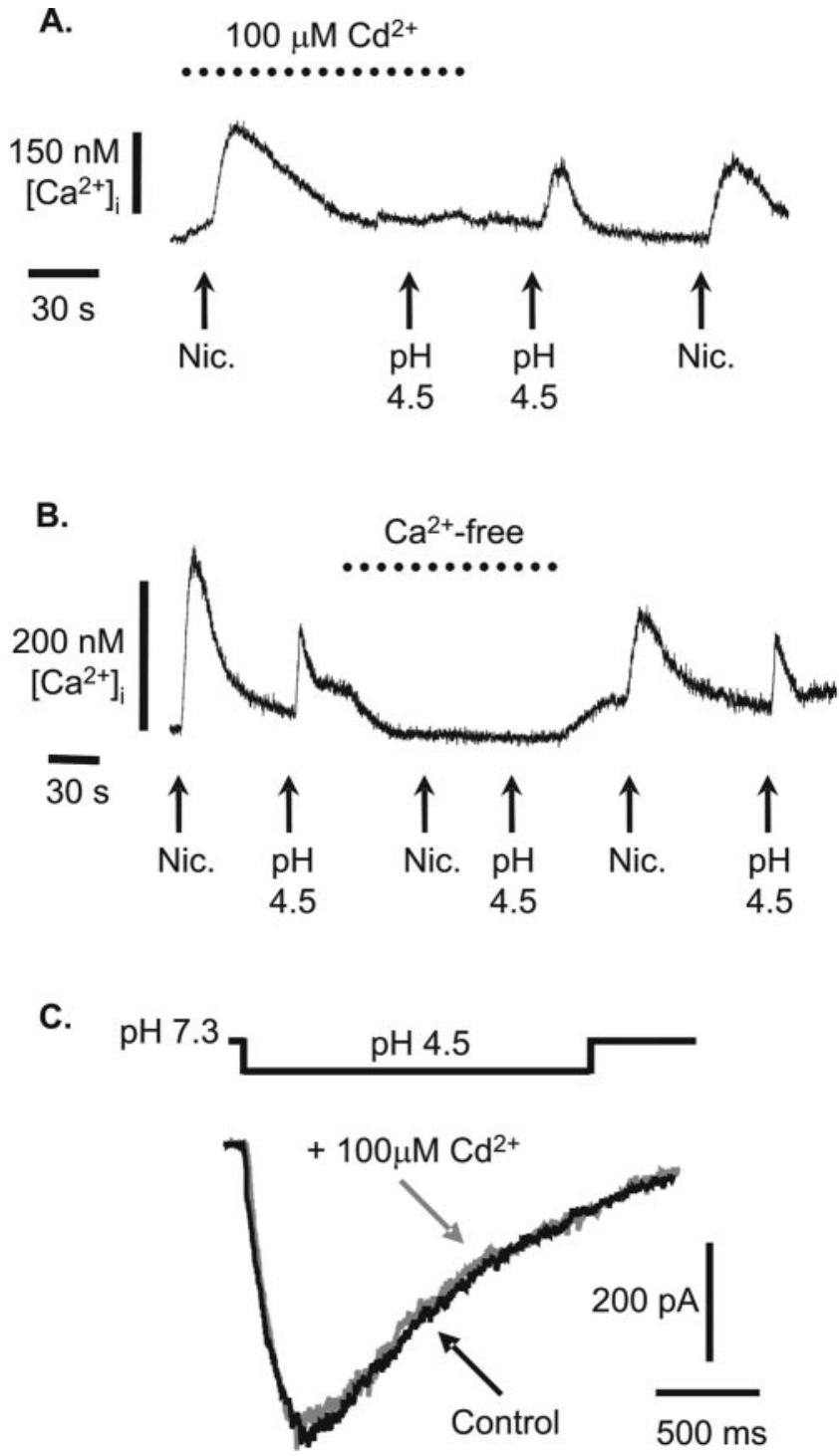

Figure 5. Intracellular $\mathrm{Ca}^{2+}$ changes in rat retinal ganglion cells in response to extracellular acidification. $A, B$, Cells were loaded with Indo-1/AM, and changes in the $405 / 488 \mathrm{~nm}$ emission ratio converted to changes in $\left[\mathrm{Ca}^{2+}\right]_{i}$ (see Materials and Methods). In the presence and absence of either $100 \mu \mathrm{M} \mathrm{Cd}^{2+}(A)$ or extracellular $\mathrm{Ca}^{2+}(B)$, cells were challenged with $100 \mu \mathrm{m}$ nicotine (nic.; positive control; $\mathrm{pH} 7.33$ ) and appropriately modified extracellular solution acidified to $\mathrm{pH} 4.5$. C, $\mathrm{pH} 4.5$-evoked currents in a voltage-clamped rat retinal ganglion cell $(-80$ $\mathrm{mV}$ ) are unaffected by the presence of $100 \mu \mathrm{m} \mathrm{Cd}^{2+}$.

reproducible decrease from a "resting" intracellular $\mathrm{Ca}^{2+}$ level of $30.4 \pm 5.8 \mathrm{nM}$ probably reflecting the effect of a reduction in driving force on calcium influx pathways involved in intracellular store refill. Figure $5 B$ demonstrates that source of the increase in $\mathrm{Ca}^{2+}$ seen in response to both nicotine and $\mathrm{pH} 4.5$ solution is extracellular in origin. Intracellular stores are not involved, because repeating applications of nicotine and $\mathrm{pH} 4.5$ solution to ganglion cells in the absence of extracellular $\mathrm{Ca}^{2+}$ prevents the control $\mathrm{Ca}^{2+}$ responses seen both before and after $(n=7)$. Moreover, during the test period in which the cell was bathed in $\mathrm{Ca}^{2+}$ free solution, a clear lowering of the baseline occurred (as seen in Fig. $5 B$ ), providing additional evidence of a degree of $\mathrm{Ca}^{2+}$ influx at rest.

$\mathrm{I}_{\mathrm{Na}(\mathrm{H}+)}$ is inhibited by amiloride

ASICs are sensitive to block by the diuretic amiloride. Therefore, $\mathrm{I}_{\mathrm{Na}(\mathrm{H}+)}$ was tested for amiloride sensitivity by pre-exposing cells



(ii) wash



(iii)



B.

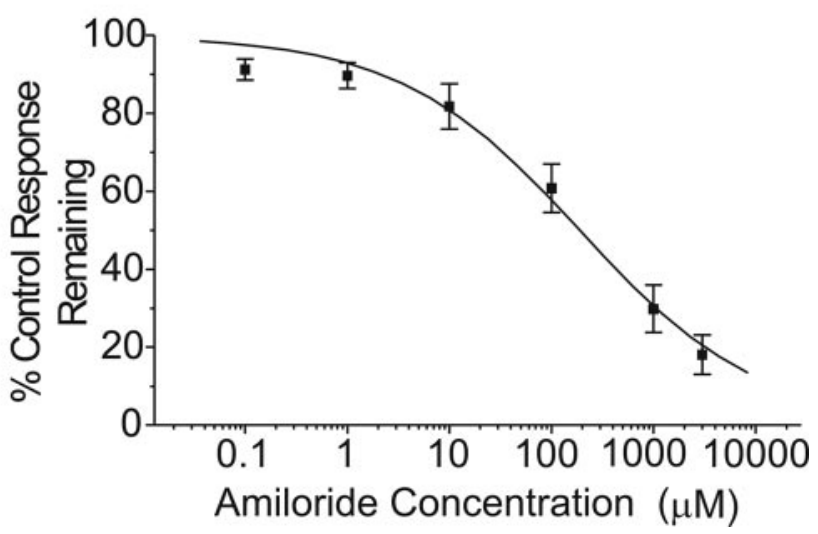

Figure 6. Effect of amiloride on the proton-gated current of rat retinal ganglion cells. $A$, $\mathrm{pH}$ 4.5-evoked currents recorded from a single voltage-clamped cell between -80 and $+40 \mathrm{mV}$ in $15 \mathrm{mV}$ increments, in the presence (i) and absence (ii) of $300 \mu \mathrm{m}$ amiloride. Aiii shows the current-voltage relationships from $A i$ (squares) and Aii (circles). $B$, Cells were voltage clamped at $-80 \mathrm{mV}$, bathed in amiloride for $60 \mathrm{sec}(0.1,1,10,100,1000$, or $3000 \mu \mathrm{m}$ in random order), and multiple $\mathrm{pH} 4.5$-evoked currents were recorded at 60 sec intervals until steady-state block was observed. Mean peak inward currents shown above ( \pm SEM; $n=5-8$ cells) have been normalized to amiloride-free control recorded just before every amiloride application. Sigmoidal curve parameters: $\mathrm{IC}_{50}, 188 \pm 39 \mu \mathrm{m}$; slope, $0.49 \pm 0.05$.

for $60 \mathrm{sec}$ to amiloride before applying pressure pulses of $\mathrm{pH} 4.5$ solution. The addition of amiloride had no effect on the $\mathrm{pH}$ of the extracellular bathing solution. Two or three responses to $\mathrm{pH} 4.5$ were then obtained (at 1 min intervals) to ensure that degree of block by the drug had reached equilibrium. The recordings shown in Figure $6 \mathrm{~A}$ were made by subjecting a single cell to the full current-voltage protocol in the presence $(A i)$ and absence (Aii) of $300 \mu \mathrm{M}$ amiloride, with the corresponding $I-V$ relationships shown in Figure 6Aiii. This example indicates that amiloride block is most effective at more negative membrane potentials. For this reason, all of the data used to compile the amiloride concentration-response curve was obtained while cells were voltage clamped at $-80 \mathrm{mV}$. Amiloride concentrations were tested in random order; each cell was washed between administrations to re-establish the control $\mathrm{pH} 4.5$ response. A plot of mean percentage inhibition of control current by each concentration of amilo- 
A. $\mathrm{pH} 4.5$



B.



C.

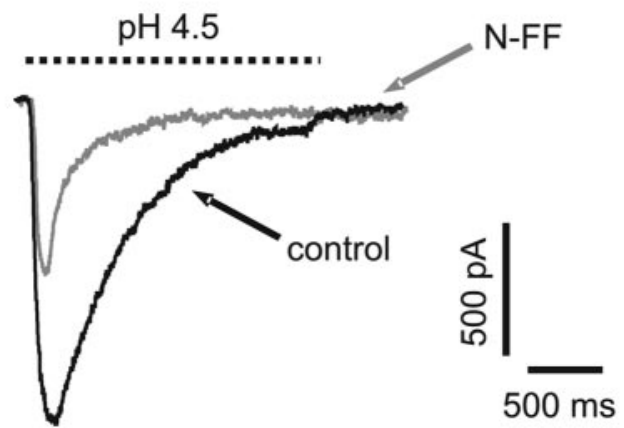

Figure 7. Modulation of retinal ganglion cell proton-gated currents by TTX, capsaicin, and neuropeptide FF. Rat retinal ganglion cells were voltage clamped at $-80 \mathrm{mV}$, and acute stimuli (dashed lines) were applied by pressure pulse. $A, \mathrm{pH}$ 4.5-evoked currents were not blocked by perfusion with $0.5 \mu \mathrm{M}$ TTX. The action of TTX was unaffected by the change in extracellular $\mathrm{pH}$. Inset, Depolarization-evoked $\mathrm{Na}^{+}$currents were still blocked by TTX in pH 4.5 extracellular solution. Spikes in the presence of TTX are uncompensated capacitance transients (see Results for explanation). $B, \mathrm{pH} 4.5$-evoked and $0.5 \mu \mathrm{m}$ capsaicin-evoked currents recorded from the same cell. C, pH 4.5-evoked currents recorded in the absence and presence of $50 \mu \mathrm{m} \mathrm{N-FF}$.

ride is shown in Figure $6 \mathrm{~B}$. This semi-log plot shows a clear concentration-dependent decrease in the size of the $\mathrm{pH}$ 4.5evoked current. The data in this figure are fitted with a logistic function, the slope of which is $0.49 \pm 0.05$. The $\mathrm{IC}_{50}$ indicated by the curve was $188 \pm 39 \mu \mathrm{M}$.

\section{Investigation of other potential modulators of $\mathrm{I}_{\mathrm{Na}(\mathrm{H}+)}$}

TTX, which blocks the majority of voltage-gated $\mathrm{Na}^{+}$currents, was tested for its effectiveness against the retinal ganglion cell proton-gated current. Pressure pulses of $\mathrm{pH} 4.5$ solution were applied to a cell voltage clamped at $-80 \mathrm{mV}$ in the absence and presence of $0.5 \mu \mathrm{M}$ TTX. In both cases, peak current and rate of desensitization were identical $(n=4)$, as illustrated in Figure 7A. The effectiveness of TTX at blocking voltage-gated $\mathrm{Na}^{+}$currents at acidic extracellular $\mathrm{pH}$ was confirmed using cells cultured for several days that had begun to develop axons and were capable of firing action potentials. These cells were perfused with $\mathrm{pH} 4.5$ extracellular solution for a few seconds, during which the command voltage was stepped from -80 to $-40 \mathrm{mV}$. The extracellular solution also contained $100 \mu \mathrm{M} \mathrm{Cd}^{2+}$ to prevent voltagegated $\mathrm{Ca}^{2+}$ channel activity. The inset in Figure $7 A$ is a voltage step in the absence (control) and presence (+TTX) of $0.5 \mu \mathrm{M}$ TTX in the same cell. Uncompensated capacitance transients are present at the beginning and end of both traces because of the extent of cell development. The additional spikes within the first trace are $\mathrm{Na}^{+}$-driven action potentials that are large enough to disrupt the voltage clamp. These are absent in the presence of TTX. Thus, the action of TTX is neither effected by extracellular acidification nor effective in blocking the proton-gated current of retinal ganglion cells.

Procaine is a lipid-soluble compound that binds to a local anesthetic site deep within the voltage-gated $\mathrm{Na}^{+}$channel pore. This alternative blocking action was tested on the RGC protongated current by applying pressure pulses of $\mathrm{pH} 4.5$ solution before and after a $1-2$ min incubation with $10 \mathrm{~mm}$ procaine $(\mathrm{pH}$ 7.33). Procaine did not significantly alter the peak amplitude or time constant of desensitization of the $\mathrm{pH} 4.5$-evoked current ( $n=4$; data not shown).

Transient receptor potential vanilloid 1 (TRPV1) channels can also conduct depolarizing currents in response to activation by protons. In rat retinal ganglion cells, the direct application of the vanilloid receptor agonist capsaicin $(0.5 \mu \mathrm{M}$, buffered to $\mathrm{pH}$ 7.33) did not evoke any depolarizing current, whereas $\mathrm{pH} 4.5$ continued to be effective in evoking responses in the same cells $(n=5$; see Fig. $7 B$ for an example).

Zinc ions have been demonstrated to enhance currents conducted via ASIC2a subunit-containing channels (Baron et al., 2001, 2002). In the present study, application of $\mathrm{ZnCl}_{2}(0.1-1$ $\mathrm{mM}$ ) to retinal ganglion cells produced a small inhibition of the acid-evoked current. At $\mathrm{pH} 4.5$, the current was inhibited by $8.8 \pm 6.7 \%$ in the presence of $300 \mu \mathrm{M} \mathrm{ZnCl}_{2}(n=4)$. At the less acid $\mathrm{pH}$ of 6.5 , the inhibition was $10.3 \pm 24.1 \%(n=3)$.

The molluscan neuropeptide FMRFamide directly activates one nonmammalian member of the EnaC-DEG superfamily of ion channels. This peptide, together with its mammalian equivalent, N-FF, has been shown to be capable of modulating both ASIC currents and proton-gated ion currents thought to be attributable to ASICs in mammalian neurons (Askwith et al., 2000). In rat retinal ganglion cells, direct application of either peptide (3-30 $\mu \mathrm{M})$ did not evoke any response $(n=6)$. However, perfusing the cells with peptide (buffered to $\mathrm{pH}$ 7.33) and then applying pressure pulses of $\mathrm{pH} 4.5$ solution revealed that both peptides could, to different degrees, modulate the proton-gated current in these cells. Surprisingly, $50 \mu \mathrm{M}$ FMRFamide had just a small effect on rate of inactivation, increasing the time constant from $585 \pm 72 \mathrm{msec}$ (mean \pm SEM) to $753 \pm 109 \mathrm{msec}(p<$ 0.05 ; paired $t$ test; $n=4$ ) with no alteration of current amplitude. The effect of $50 \mu \mathrm{M} \mathrm{N}-\mathrm{FF}$ was much more pronounced, with a marked reduction in peak current amplitude and shortening of the time constant of inactivation. Figure $7 C$ shows an example of this effect. In three cells tested, the time constant decreased significantly from $532 \pm 74$ to $225 \pm 26 \mathrm{msec}(p<0.05$; paired $t$ test).

The effect of acute exposure to acid on RGC electrical activity RGCs are unique among retinal neurons in that they can sustain prolonged electrical activity in the form of trains of action potentials (Dowling, 1987) (Fig. 8, inset). To trigger these all-ornothing responses, they require depolarization from resting potential in the order of $20-30 \mathrm{mV}$. Would the depolarization 




B



Figure 8. $A, B$, Electrical activity recorded from a current-clamped rat retinal ganglion cell in response to a $1 \mathrm{sec}, 20 \mathrm{pA}$ current injection $(A)$ and pressure application of $\mathrm{pH} 6.5$ for $1 \mathrm{sec}, 8 \mathrm{psi}$ $(B)$. Resting $V_{m},-78 \mathrm{mV}$. Inset shows strong repetitive firing in response to a $1 \mathrm{sec}, 50 \mathrm{pa}$ current injection.

caused by transient extracellular acidification be sufficient to trigger action potential generation? With mean cell input resistances of $1.54 \pm 0.7 \mathrm{G} \Omega(n=50)$, just $16.2 \mathrm{pA}$ would be required to elicit a change in membrane potential of $25 \mathrm{mV}$. Because currents of this magnitude were generated by $\mathrm{pH} 6.5$, pressure pulses of $\mathrm{pH}$ 6.5 solution were applied to cells held in current-clamp mode at their resting potential. Figure 8 shows a single RGC from which electrical responses to both current injection $(A)$ and acute acidification $(B)$ were recorded ( $V_{\text {rest }}$ in this example was $-78 \mathrm{mV}$ ). Current injection of $20 \mathrm{pA}$ was the minimum required for this particular cell to reach action potential threshold (estimated at $-45 \mathrm{mV}$ from Fig. 8A). Pressure-pulse application $\mathrm{pH}$ 6.5, demonstrated above as the threshold $\mathrm{pH}$ for current activation in RGCs, evoked similar short trains of action potentials $(n=3)$. However, at the more acid $\mathrm{pH}$ of 6.0 , just one cell produced an action potential and, in an additional 17 cells, only sustained depolarization beyond action potential threshold was seen.

\section{Discussion}

This is the first description of a proton-gated current in mammalian retinal neurons. Recently, Brockway et al. (2002) detected ASIC1, 2, 3, and 4 mRNA in rabbit retina and demonstrated the presence of an amiloride-sensitive current in retinal glial (Müller) cells. In mouse retina, ASIC3 mRNA has also been identified
(Maubaret et al., 2002). Consistent with these findings, the rat retina as a whole also appears to contain most of the ASIC subunits cloned to date, with ASICs 1a and 2a particularly abundant. The combined electrophysiological and RT-PCR data presented here suggest that ASIC the mRNA detected encodes proteins that form functional ion channels in the retina. No attempt has been made in this study to localize subunit expression within the laminar organization of retinal neurons, although other subunits from the closely related EnaC-DEG family have been detected previously in the ganglion cell layer using immunocytochemistry and in situ hybridization (Matsuo, 1998; Mirshahi et al., 1999; Golestaneh et al., 2000).

\section{$\mathrm{I}_{\mathrm{Na}(\mathrm{H}+)}$ in rat retinal ganglion cells}

$\mathrm{I}_{\mathrm{Na}(\mathrm{H}+)}$ shares most of the characteristics of currents recorded from cells transfected with ASIC proteins. When stimulated by the fast application of protons under physiological recording conditions and at resting membrane voltages, RGCs exhibit a rapidly activating inward current which, from Nernstian shifts in reversal potential with $\mathrm{E}_{\mathrm{Na}}$, is carried by $\mathrm{Na}^{+}$ions. RGC protongated channels do not appear to be $\mathrm{Ca}^{2+}$ permeant, nor do they show any voltage dependence of activation. During prolonged applications of acid, the current desensitizes completely, the time constant of which (in the region of $600 \mathrm{msec}$ ) shows no clear dependence on membrane potential or $\mathrm{pH}$. These features also relate to currents conducted via channels containing ASICs 1a, $1 \mathrm{~b}$, or $2 \mathrm{a}$, although RT-PCR results showed ASIC1b is not present in the retina. The absence of a steady-state current in the continued presence of acid and the $\mathrm{Na}^{+}$selectivity of $\mathrm{I}_{\mathrm{Na}(\mathrm{H}+)}$ suggests that ASIC3, or the modulatory subunit $2 \mathrm{~b}$, does not contribute to this current. $\mathrm{I}_{\mathrm{Na}(\mathrm{H}+)}$ is reversibly inhibited by amiloride but, in contrast to other ASIC currents, the $\mathrm{IC}_{50}$ of $188 \mu \mathrm{M}$ appears relatively large. This probably reflects the use of stronger acid $(\mathrm{pH}$ 4.5 here; approximately $\mathrm{pH} 6.0$ elsewhere) in generating the amiloride concentration-inhibition curve, as observed by Sutherland et al. (2001). $\mathrm{I}_{\mathrm{Na}(\mathrm{H}+)}$ activation occurs as the extracellular pH falls below pH $6.5\left(300 \mathrm{nM}\left[\mathrm{H}^{+}\right]\right)$, similar to the activation of homomeric ASIC 1a channels (Waldmann et al., 1997). In contrast, half-maximal and maximal activation occurs at much more acidic levels, closer to those of ASIC2a (Lingueglia et al., 1997). Cotransfection of rat ASIC 1a and 2a produces channels with these activation characteristics. Furthermore, a high degree of colocalization of these subunits exists within brain neurons (Bassilana et al., 1997), and strong evidence of both subunits was found here in the retina. However, the lack of enhancement of $\mathrm{I}_{\mathrm{Na}(\mathrm{H}+)}$ by $\mathrm{ZnCl}_{2}$ would suggest that the channels do not contain ASIC2a, because it has been reported that $\mathrm{Zn}^{2+}$ enhancement is diagnostic of ASIC2a-containing channels (Baron et al., 2001, 2002). In the absence of electrophysiological data from heteromultimers containing the "silent" subunit ASIC 4, these data suggest that the proton-gated current of rat RGCs is conducted via a heteromultimeric channel containing ASIC1a and possibly ASIC4. Other as yet unidentified subunits may also contribute.

$\mathrm{I}_{\mathrm{Na}(\mathrm{H}+)}$ also shows many similarities with native proton-gated currents recorded from other regions of the mammalian brain. All require rapid ( $\mathrm{msec}$ ) acidification to activate, all are insensitive to block by conventional voltage-gated $\mathrm{Na}^{+}$channel antagonists (demonstrated here with TTX and procaine), and their rapid recovery from desensitization plus voltage insensitivity distinguishes them from TRPV1 receptor activity. In terms of tissuespecific differences, the sensitivity of the retinal ganglion cell current to small changes in extracellular $\mathrm{pH}$ is reduced, which is 
perhaps predictable for a tissue with an enhanced level of metabolic activity.

FMRFamide, which activates the nonmammalian peptidegated relatives of ASICs, and the structurally similar mammalian peptide N-FF are known to significantly potentiate certain ASIC currents (Askwith et al., 2000; Catarsi et al., 2001; Allen and Attwell, 2002). These effects have so far only been observed in ASIC1 or ASIC3 homomers and ASIC2a and 3 heteromeric channels. Neither peptide potentiated $\mathrm{I}_{\mathrm{Na}(\mathrm{H}+)}$, but considering that the electrophysiological and pharmacological characteristics of the current preclude ASIC2a and 3 involvement, this result is not surprising. What was surprising, however, was that N-FF significantly decreased current magnitude and shortened the time constant of desensitization. Whether N-FF itself is endogenous to the retina has yet to be established, but mRNAs encoding closely related RFamide-related peptides have recently been found in very high levels in the eyes of rats as well as the human retina (Hinuma et al., 2000), which may provide local modulation of the function of ASICs in the visual system.

\section{Physiological role}

From the current-clamp recordings shown in Figure 8, rapid but weak extracellular acidification appears to evoke the normal pattern of electrical activity associated with RGCs. However, at more acidic levels (more than pH 6.5), the effect is to depolarize the cell evoking none or a single action potential (presumably because of the "shunting effect" of opening a large number of channels or the inactivation of sodium channels). Protons therefore provide a way of modulating the excitability of these cells. The ability to detect extracellular acidification is an understandable characteristic of cells involved in nociception (e.g., DRGs) and taste. Yet, in the retina (and the CNS in general), extracellular $\mathrm{pH}$ is tightly regulated, and even under strong light or electrical stimulation pH fluxes do not exceed $0.1 \mathrm{pH}$ unit (Borgula et al., 1989; Yamamoto et al., 1992). The largest activity-induced fluxes (up to $0.3 \mathrm{pH}$ units) have been recorded in the mammalian optic nerve (Davis et al., 1987). With resting retinal $\mathrm{pH}$ levels within the range of pH 7.2-7.4 (Padnick-Silver and Linsenmeier, 2002), the most extreme acidification might result in the lowering of retinal $\mathrm{pH}$ to 6.9 , which would be insufficient to activate $\mathrm{I}_{\mathrm{Na}(\mathrm{H}+)}$. If this current does contribute to gross retinal physiology, it may require modulation by some other locally released factor such as a neuropeptide, or even activation by a stimulus other than protons. On the basis of their observations of ASIC3, ASIC1a, and native neuronal acid-evoked currents, Immke and McCleskey (2003) recently proposed that rather than directly activating the current, protons open ASIC channels by catalyzing the relief of channel block by calcium. The observation that a reduction in extracellular calcium enables ASICs to activate at less acidic $\mathrm{pH}$ levels suggests that local calcium homeostasis may play a significant role in the control of these channels (Korkushco et al., 1983; Babini et al., 2002).

Alternatively, local $\mathrm{pH}$ levels within synaptic clefts may fluctuate over a wider dynamic range (Krishtal, 2003). In mammalian cone photoreceptors, it has been suggested that release of vesicular protons can modulate presynaptic calcium currents and ultimately neurotransmitter release (DeVries, 2001). Additional evidence for the role of transient acidification and ASIC function in synaptic transmission comes from the observations that ASIC knock-out mice display altered synaptic potentials in the hippocampus (Wemmie et al., 2002). Until additional studies in the retina and on the visual system of ASIC knock-out mice are per- formed, any physiological role of $\mathrm{I}_{\mathrm{Na}(\mathrm{H}+)}$ in RGCs remains unclear.

\section{Pathophysiology}

Although physiological changes in $\mathrm{pH}$ may be small, there is evidence that changes resulting from ischemia may be much larger. Indeed, in the brain, ASIC expression is induced during ischemia (Johnson et al., 2001), and ASIC channel currents are modulated by substances released during ischemic episodes (Allen and Attwell, 2002). Retinal ischemia and other pathologies such as glaucoma also involve a decrease in extracellular $\mathrm{pH}$ and the selective loss of RGCs (Ikeda et al., 1992; Lu et al., 2001). If ASICs are part of a mechanism whereby the $\mathrm{pH}$ flux contributes to the death of these cells, they present a worthwhile target for therapeutic investigation.

Note added in proof. While this work was in proof, an article showing that $\mathrm{Zn}^{2+}$ inhibits only ASIC1a currents was published (Chu et al., 2003), supporting our case that the ASICIa subunit is the most likely candidate mediating $\mathrm{I}_{\mathrm{Na}(\mathrm{H}+)}$ in RGCs.

\section{References}

Allen NJ, Attwell D (2002) Modulation of ASIC channels in rat cerebellar purkinje neurons by ischaemia-related signals. J Physiol (Lond) 543:521-529.

Askwith CC, Cheng C, Ikuma M, Benson C, Price MP, Welsh MJ (2000) Neuropeptide FF and FMRFamide potentiate acid-evoked currents from sensory neurons and proton-gated DEG/ENaC channels. Neuron 26:133-141.

Babini E, Paukert M, Geisler HS, Grunder S (2002) Alternative splicing and interaction with di- and polyvalent cations control the dynamic range of acid-sensing ion channel (ASIC) 1. J Biol Chem 26:41597-41603.

Baron A, Schaefer L, Lingueglia E, Champigny G, Lazdunski M (2001) $\mathrm{Zn}^{2+}$ and $\mathrm{H}^{+}$are coactivators of acid-sensing ion channels. J Biol Chem 276:35361-35367.

Baron A, Waldmann R, Lazdunski M (2002) ASIC-like, proton activated currents in rat hippocampal neurons. J Physiol (Lond) 539:485-494.

Bassilana F, Champigny G, Waldmann R, de Weille JR, Heurteaux C, Lazdunski M (1997) The acid-sensitive ionic channel subunit ASIC and the mammalian degenerin MDEG forma heteromultimeric $\mathrm{H}^{+}$-gated $\mathrm{Na}^{+}$ channel with novel properties. J Biol Chem 272:28818-28822.

Bassler E-L, Ngo-Anh TJ, Geisler H-S, Ruppersberg JP, Grunder S (2001) Molecular and functional characterisation of acid-sensing ion channel (ASIC) 1b. J Biol Chem 276:33782-33787.

Baumann TK, Burchiel KJ, Ingram SL, Martenson ME (1996) Responses of adult human dorsal root ganglion neurons in culture to capsaicin and low pH. Pain 65:31-38.

Benson CJ, Sutherland SP (2001) Toward an understanding of the molecules that sense myocardial ischemia. Ann NY Acad Sci USA 940:96-109.

Borgula GA, Steinberg RH, Karwoski CJ (1989) Light-evoked changes in extracellular pH in frog retina. Vision Res 29:1069-1077.

Brockway LM, Zhou ZH, Bubien JK, Jovov B, Benos DJ, Keyser KT (2002) Rabbit retinal neurons and glia express a variety of ENaC/DEG subunits. Am J Physiol 283:C126-C134.

Catarsi S, Babinski K, Séguéla P (2001) Selective modulation of heteromeric ASIC proton-gated channels by neuropeptide FF. Neuropharmacol 41:592-600.

Chesler M (1990) The regulation and modulation of $\mathrm{pH}$ in the nervous system. Prog Neurobiol 34:401-427.

Chomczynski P, Sacchi N (1987) Single-step method of RNA isolation by acid guanidinium thiocyanate phenol chloroform extraction. Anal Biochem 162:156-159.

Chu XP, Zhu XM, Wemmie JA, Price MP, Saugstad JA, Simon RP, Welsh MJ, Xiong ZG (2003) Subunit-dependent high affinity zinc inhibition of acid-sensing ion channels. Soc Neurosci Abstr 29:308.7.

Davis PK, Carlini WG, Ransom BR, Black JA, Waxman SG (1987) Carbonic-anhydrase activity develops postnatally in the rat optic-nerve. Dev Brain Res 31:291-298.

de la Rosa DA, Canessa CM, Fyfe GK, Zhang P (2000) Structure and regulation of amiloride-sensitive sodium channels. Ann Rev Physiol 62:573-594. 
DeVries SH (2001) Exocytosed protons feedback to suppress the $\mathrm{Ca}^{2+}$ current in mammalian cone photoreceptors. Neuron 32:1107-1117.

de Weille JR, Bassilana FR, Lazdunski M, Waldmann R (1998) Identification, functional expression and chromosomal localisation of a sustained human proton-gated cation channel. FEBS Lett 433:257-260.

Dowling JE (1987) The retina: an approachable part of the brain, pp 82-83. Belknap: Harvard UP.

Gilbertson TA, Roper SD, Kinnamon SC (1993) Proton currents through amiloride-sensitive $\mathrm{Na}^{+}$channels in isolated hamster taste cells-enhancement by vasopressin and cAMP. Neuron 10:931-942.

Golestaneh N, Nicolas C, Picaud S, Ferrari P, Mirshahi M (2000) The epithelial sodium channel $(\mathrm{ENaC})$ in rodent retina, ontogeny and molecular identity. Curr Eye Res 21:703-709.

Hayat S, Wigley CB, Robbins J (2003) Intracellular calcium handling in rat olfactory ensheathing cells and its role in axonal regeneration. Mol Cell Neurosci 22:259-270.

Hinuma S, Shintani Y, Fukusumi S, Lijima N, Matsumoto Y, Hosoya M, Fujii R, Watanabe T, Kikuchi K, Terao Y, Yano T, Yamamoto T, Kawamata Y, Habata Y, Asada M, Kitada C, Kurokawa T, Onda H, Nishimura O, Tanaka M, Ibata Y, Fujino M (2000) New neuropeptides containing carboxy-terminal RFamide and their receptor in mammals. Nat Cell Biol 2:703-708.

Ikeda H, Hankins MW, Asai T, Dawes EA (1992) Electrophysiological properties of neurons following mild and acute retinal ischemia. Exp Eye Res 55:435-442.

Immke DC, McCleskey EW (2003) Protons open acid-sensing ion channels by catalyzing relief of $\mathrm{Ca}^{2+}$ blockade. Neuron 37:75-84.

Johnson MB, Jin K, Minami M, Chen D, Simon RP (2001) Global ischemia induces expression of acid-sensing ion channel $2 \mathrm{a}$ in rat brain. J Cereb Blood Flow Metab 21:734-740.

Krishtal O (2003) The ASICs: signaling molecules? modulators? Trends Neurosci 26:477-483.

Korkushco AO, Krishtal OA, Chernevskaya NI (1983) Steady-state characteristics of the proton receptor in the somatic membrane of rat sensory neurons. Neirofiziologiia 15:632-638.

Kovalchuk YN, Krishtal OA, Nowycky MC (1990) The proton-activated inward current of rat sensory neurons includes a calcium component. Neurosci Lett 115:237-242.

Li YX, Schaffner AE, Li HR, Nelson R, Barker JL (1997) Proton-induced cation current in embryonic rat spinal cord neurons changes ion dependency over time in vitro. Dev Brain Res 102:261-266.

Lilley SJ (2001) The discovery and characterisation of a proton-gated sodium current in rat retinal ganglion cells. $\mathrm{PhD}$ thesis, University of London.

Lilley S, Robbins J (2001) Characterisation of a novel proton-gated sodium current in rat retinal ganglion cells. J Physiol (Lond) 531:83P-84P.
Lingueglia E, deWeille JR, Bassilana F, Heurteaux C, Sakai H, Waldmann R, Lazdunski M (1997) A modulatory subunit of acid sensing ion channels in brain and dorsal root ganglion cells. J Biol Chem 272:29778-29783.

Lu DW, Chang CJ, Wu JN (2001) The changes of vitreous $\mathrm{pH}$ values in an acute glaucoma rabbit model. J Occ Pharmacol Ther 17:343-350.

Matsuo T (1998) Expression of amiloride-sensitive sodium channel in rat eye. Acta Medica Okayama 52:279-283.

Maubaret C, Delettre C, Sola S, Hamel CP (2002) Identification of preferentially expressed mRNAs in retina and cochlea. DNA Cell Biol 21:781-791.

Mirshahi M, Nicolas C, Mirshahi S, Golestaneh N, d'Hermies F, Agarwal MK (1999) Immunochemical analysis of the sodium channel in rodent and human eye. Exp Eye Res 69:21-32.

Padnick-Silver L, Linsenmeier RA (2002) Quantification of in vivo anaerobic metabolism in the normal cat retina through intraretinal $\mathrm{pH}$ measurements. Vis Neurosci 19:793-806.

Price MP, Lewin GR, McIlwrath SL, Cheng C, Xie JH, Heppenstall PA, Stucky CL, Mannsfeldt AG, Brennan TJ, Drummond HA, Qiao J, Benson CJ, Tarr DE, Hrstka RF, Yang BL, Williamson RA, Welsh MJ (2000) The mammalian sodium channel BNC1 is required for normal touch sensation. Nature 407:1007-1011.

Reeh PW, Steen KH (1996) Tissue acidosis in nociception and pain. Prog Brain Res 113:143-151.

Robbins J, Reynolds AM, Treseder S, Davies R (2003) Enhancement of lowvoltage-activated calcium currents by group II metabotropic glutamate receptors in rat retinal ganglion cells. Mol Cell Neurosci 23:341-350.

Robinson RA, Stokes RH (1959) Electrolyte solutions, Sec 5, p 4. London: Butterworth.

Sutherland SP, Benson CJ, Adelman JP, McCleskey EW (2001) Acidsensing ion channel 3 matches the acid-gated current in cardiac ischemiasensing neurons. Proc Natl Acad Sci USA 98:711-716.

Ueno S, Nakaye T, Akaike N (1992) Proton-induced sodium current in freshly dissociated hypothalamic neurons of the rat. J Physiol (Lond) 447:309-327.

Varming T (1999) Proton-gated ion channels in cultured mouse cortical neurons. Neuropharmacol 38:1875-1881.

Waldmann R, Champigny G, Bassilana F, Heurteaux C, Lazdunski M (1997) A proton-gated cation channel involved in acid-sensing. Nature 386:173-177.

Wemmie JA, Chen J, Askwith CC, Hruska-Hageman AM, Price MP, Nolan BC, Yoder PG, Lamani E, Hoshi, Freeman JH, Welsh MJ (2002) The acid-activated ion channel ASIC contributes to synaptic plasticity, learning and memory. Neuron 34:463-477.

Yamamoto F, Borgula GA, Steinberg RH (1992) Effects of light and darkness on $\mathrm{pH}$ outside rod photoreceptors in the cat retina. Exp Eye Res 54:685-697. 